\title{
ANALISA KEKUATAN INTERNAL DAN PERUBAHAN EKSTERNAL DALAM MENENTUKAN STRATEGI DAYA SAING PERUSAHAAN
}

\author{
Abi Hanif Dzulquarnain \\ Departemen Manajemen, Universitas Muhammadiyah Gresik, Gresik, Indonesia \\ dzulquarnain_abihanif@umg.ac.id
}

\begin{abstract}
Background - Strategy formulation is often a complicated process that requires adopting a systematic approach to diagnosing external factors and to match these external factors with internal capabilities, therefore strategy formulation is an important measure of a company's success in winning the competition at the national level or maybe even at the international level.

Purpose - This study aims to provide an academic paper on freight

Diterima : 01 April 2021

Direview : 06 April 2021

Direvisi : 03 Mei 2021

Disetujui : 17 Mei 2021 Forwarder company management which is the object of research in determining future company strategies by identifying SWOT and TOWS in order to uncover strategies to exploit strengths and opportunities as well as to improve weaknesses and overcome these threats.

Design/ Methodology/ Approach - This study uses a qualitative approach in answering the formulation of research problems. The data collection method consists of a comprehensive review of the literature and a part of interviews with management executives at freight forwarders. Data analysis uses the IFE approach and the EFE Matrix, to map the scores and weightings of internal strengths and external changes.

Result and Discussion - Combining the IFE and EFE analysis, we get a company positioning plot at the medium or hold and maintain level, which means that the company's current focus is on market penetration and product / service development.

Conclusion - The TOWS matrix produces a series of proposed strategies, namely SO, WO, ST, and WT that echo internal and external conditions, so it is hoped that the four proposed strategies will be able to increase the competitiveness of companies in the national arena.

Research Limitation - This research is limited to companies within the scope of freight forwarders in the city of Surabaya. Research in different years with the same variables is suggested to be carried out in the future, considering that internal changes and external changes will follow changes in time.

Research Implications - This research can be used as a reference for other companies in the freight forwarder sector to determine the direction of the company's future strategy, however, these results are only valid for companies that are the object of research, all variables must be changed and adjusted to the conditions of each company. the proposed strategy becomes valid.

Acknowledgment - This research was carried out in collaboration with companies in the field of freigt forwarders in the city of Surabaya, along with their leaders who took the time and willingness to complete this research study.
\end{abstract}

Keywords : Strength, Exchange, Strategy, Freight, Forwarder

\begin{abstract}
ABSTRAK
Latar Belakang - Perumusan strategi seringkali merupakan proses yang rumit yang memerlukan adopsi pendekatan sistematis untuk mendiagnosis faktor eksternal dan untuk mencocokkan faktor eksternal ini dengan kemampuan internal yang oleh karenanya perumusan strategi menjadi tolak ukur penting keberhasilan perusahaan dalam memenangkan persaingan di tingkat nasional atau mungkin bahkan ditingkat internasional.

Tujuan - Penelitian ini bertujuan memberikan naskah akademis pada manajemen perusahaan freight forwarder yang dijadikan objek penelitian dalam menentukan strategi perusahaan kedepan dengan mengidentifikasi SWOT dan TOWS guna mengungkap strategi untuk memanfaatkan kekuatan dan peluang serta memperbaiki kelemahan serta mengatasi ancaman tersebut.

Desain/ Metodologi/ Pendekatan - Penelitian ini menggunakan pendekatan kualitatif dalam menjawab rumusan masalah penelitian. Metode pengumpulan data terdiri tinjauan komprehensif literatur dan bagian wawancara dengan eksekutif manajemen di perusahaan freight forwarder. Analisa data
\end{abstract}


menggunakan pendekatan IFE dan EFE Matriks, untuk memetakan skor dan pembobotan kekuatan internal dan perubahan eksternal.

Hasil dan Pembahasan - Menggabungkan pada analisis IFE dan EFE, maka didapatkan plot positioning perusahaan pada tingkat medium atau hold and maintain, yang artinya adalah fokus perusahaan untuk saat ini adalah ke market penetration dan pengembangan produk/ layanan.

Kesimpulan - TOWS matrik menghasilkan rangkaian usulan strategi yakni SO, WO, ST, dan WT yang menggaungkan kondisi interal dan kondisi eksternal, sehingga harapannya keempat strategi yang diusulkan mampu menaikkan daya saing perusahaan di kancah nasional.

Batasan Penelitian - Penelitian ini terbatas pada perusahaan di lingkup freight forwarder yang ada di kota Surabaya. Penelitian di tahun yang berbeda dengan variabel yang sama disarankan untuk dilakukan kedepan, mengingat perubahan internal dan perubahan eksternal akan mengikuti perubahan waktu.

Implikasi Penelitian - Penelitian ini dapat dijadikan sebagai rujukan bagi perusahaan lain di bidang freight forwarder untuk menentukan arah strategi perusahaan kedepannya, namun demikian hasil ini hanya valid pada perusahaan yang menjadi objek penelitian, seluruh variabel harus diubah dan disesuaikan dengan kondisi perusahaan masing-masing agar hasil strategi yang diusulkan menjadi valid. Acknowledgement - Penelitian ini terlaksana dengan kerjasama perusahaan di bidang freigt forwarder di Kota Surabaya, beserta jajaran pimpinannya yang meluangkan waktu dan kesediannya untuk melengkapi kajian penelitian ini.

Kata Kunci : Kekuatan, Perubahan, Strategi Perusahaan, Freight, Forwarder

\section{PENDAHULUAN}

Memasuki abad ke 21 persaingan antar perusahaan baik yang bergerak dibidang manufaktur maupun pelayanan jasa tidak lagi sama. Pelanggan pada abad ke 21 diberkahi dengan kemajuan teknologi terkini yang dampak dari kemajuan teknologi tersebut mereka dapat melakukan akses, menelaah, memilah, memberikan penilaian, maupun menanyakan semua informasi terkait dengan produk atau pelayanan jasa yang akan atau hendak dimiliki (Zhu, 2004). Dampak nyata dari fenomena diatas adalah perusahaan semakin selektif dan ketat terhadap bagaimana mereka menjalankan proses bisnisnya guna menghasilkan produk maupun pelayanan jasa yang sesuai dengan persepsi dan ekspektasi pelanggan.
Intelijen transportasi (laporan Global Freight Forwarding, 2016), sebuah firma riset pasar, memperkirakan pengiriman barang global pada tahun 2016 adalah US \$ 141,9 miliar, menunjukkan pertumbuhan 2,7 persen, dan pertumbuhan volume kargo diperkirakan 2,6 persen jika dibandingkan hingga 2015, dengan pertumbuhan 2,1 persen dalam nilai/ pendapatan dan pertumbuhan 2,0 persen dalam volume kargo. 60 persen pasar kargo global dikendalikan oleh 20 perusahaan ekspedisi teratas. Perusahaan ekspedisi lain hampir menguasai 40,5 persen pangsa pasar.

Isu diatas merupakan kesempatan dan sekaligus wajah dari lingkungan eksternal perusahaan freight forwarder, kondisi berubahnya lingkungan eksternal menjadi kunci yang perlu menjadi peratian bagi manajemen organisasi bisnis dalam 
menentukan strategi perusahaan kedepannya (David, 2009), yang dengan demikian akan menjadi dasar urgensi pentingnya dalam menganalisa strategik perusahaan terhadap berubahnya lingkungan tersebut.

Perumusan strategi seringkali merupakan proses rumit yang memerlukan adopsi pendekatan sistematis untuk mendiagnosis faktor eksternal dan untuk mencocokkan faktor eksternal ini dengan kemampuan internal organisasi (Weihrich, 1999). Perumusan dan implementasi strategis selalu merupakan tanggung jawab utama bagi para eksekutif puncak dalam organisasi bisnis mana pun (Koo et al., 2011).

Pengembangan strategi adalah tentang menganalisis keadaan yang ada dan yang diinginkan dan kemudian memutuskan cara yang paling efektif (bagaimana) untuk mencapai tujuan masing-masing (apa). Faktor eksternal adalah masalah yang tidak dapat dipengaruhi oleh entitas yang bersangkutan, namun entitas tersebut terpengaruh olehnya (Koo et al., 2011).

Perumusan strategi perusahaan tidak hanya bertolak pada lingkungan eksternal saja namun juga melihat lingkungan internal, dalam hal ini kekuatan internal apa saja yang dimiliki oleh perusahaan untuk memastikan keberlangsungan perusahaan kedepannya. Faktor internal adalah elemen yang dapat diubah dan dimanipulasi oleh entitas terkait (David, 2009). Kegagalan dan keberhasilan suatu entitas terkait erat dengan seberapa efektif strategi dikembangkan, diterapkan, dan dipantau. Sektor bisnis, terdapat berbagai macam pendekatan yang berbeda untuk pengembangan strategis, salah satunya adalah menggunakan Analisis SWOT dan analisis TOWS (Koo et al., 2009).

Perencanaan strategik bagi perusahaan freight forwarder mencuat seiring dengan adanya perubahan dinamik dari kondisi lingkungan internal dan eksternal. Selama dua dekade terakhir, perubahan signifikan dalam logistik dan layanan pengiriman barang terjadi, tren pasar baru, privatisasi, transisi ekonomi, inklusi di pasar terbuka dan global telah secara signifikan mengubah operasi bisnis perusahaan pengiriman barang (Killibarda et al., 2016). Perusahaan ekspedisi selalu berada dalam dilema mengenai kualitas layanan yang diminta dan diharapkan klien, yaitu sejauh mana layanan yang ditawarkan dan disediakan memenuhi harapan klien. Untuk menjawab pertanyaan yang diajukan dengan sukses, kualitas layanan harus terus diukur, dipantau, dan ditingkatkan (Ding and Tsai, 2012).

Mengembangkan bentuk strategik bagi perusahaan freight forwarder memerlukan pendekatan dan studi yang kompregesif. 
Alat (tools) strategik sebagai pendekatan dipilih bukan karena kecanggihannya, namun kemampuannya dalam memberikan gambaran kondisi real di perusahaan freight forwarder (Koo et al., 2011). SWOT adalah alat perencanaan strategis yang digunakan sebagai pendekatan sistematis untuk membantu proses pengambilan keputusan. Hal ini adalah pendekatan terkenal yang digunakan peneliti dan praktisi. Meskipun dapat membantu menentukan faktor strategis bagi perusahaan (Aktan, 2008), hal ini tidak memadai dalam menemukan derajat kepentingan alternatif yang mungkin. Teknik pengambilan keputusan multi-kriteria dapat membantu mengatasi kekurangan.

Penelitian ini bertujuan memberikan naskah akademis pada manajemen perusahaan freight forwarder yang dijadikan objek penelitian dalam menentukan strategi perusahaan kedepan dengan identifikasi SWOT dan TOWS guna mengungkap strategi untuk memanfaatkan kekuatan dan peluang serta memperbaiki kelemahan serta mengatasi ancaman tersebut.

\section{TINJAUAN PUSTAKA}

Strategi didefinisikan sebagai penentuan tujuan dan sasaran dasar dari suatu perusahaan dan adopsi tindakan dan alokasi sumber daya yang diperlukan untuk melaksanakan tujuan tersebut (Feurer dan
Chaharbaghi, 1997). Sederhananya, strategi adalah alat untuk mencapai tujuan perusahaan yang penting dan berjangka panjang. Tujuan strategis yang berarti harus: spesifik, terukur, dapat dicapai, berorientasi pada hasil, dan terikat waktu (yaitu SMART). Pendekatan perumusan strategi yang pragmatis dan efektif hendaknya: mudah diterapkan, relevan, efektif, efisien, sistematis, demokratis, melibatkan pihak terkait, fleksibel, mudah dipahami, komprehensif, dan ringkas (Koo et al., 2009).

\section{SWOT Analysis Review}

Kekuatan atau kelemahan, dan peluang atau ancaman eksternalnya (SWOT) analisis adalah analisis kekuatan dan kelemahan yang ada secara internal dalam organisasi, ditambah dengan peluang dan ancaman yang dihadapi organisasi secara eksternal (Lynch, 2012). Analisis SWOT dikategorikan menjadi kekuatan dan kelemahan (masalah internal) peluang dan ancaman (masalah eksternal). Selanjutnya, analisis SWOT adalah alat perencanaan strategis dan dapat ditelusuri kembali sejak 1969 oleh Learned et al. (1969), dan saat ini, ini adalah salah satu teknik formulasi strategis yang paling dikenal dan mapan (Panagiotou, 2003). Pemisahan Masalah lingkungan dilakukan menjadi masalah internal menyangkut citra, struktur, ketersediaan sumber daya 
berwujud dan tidak berwujud, kapabilitas dan produktivitas serta ke dalam masalah eksternal yang berkaitan dengan skenario politik, gejolak ekonomi, perubahan sosial dan teknologi, dan masalah lingkungan. Proctor (1992) menyatakan bahwa analisis SWOT cocok untuk diikuti oleh negara, industri atau organisasi, karena mengidentifikasi hubungan lingkungan antara lingkungan internal dan eksternal.

Penggunaan analisis SWOT menyediakan platform untuk mengenali posisi masa depan yang disukai, mengidentifikasi masalah, dan ini disetujui oleh banyak peneliti (David, 2009). Selain itu, analisis SWOT akan memungkinkan para perencana memiliki pemahaman yang lebih baik tentang bagaimana mengubah kelemahan menjadi kekuatan dengan memanfaatkan peluang dan menyadari bagaimana ancaman dapat menjadi peluang dengan menggunakan kekuatan tersebut. Analisis SWOT sudah komprehensif, mulai dari perumusan strategi untuk masingmasing perusahaan, industri, pemerintah, organisasi internasional bahkan studi kontinental.

\section{TOWS Matriks}

TOWS Matriks adalah alat yang dapat membantu manajer mengembangkan empat tipe strategi: SO (kekuatan-peluang strengths-opportunities), WO (kelemahan- peluang weaknesses-opportunities), ST (kekuatan-ancaman strengths-threats), WT (kelemahan-ancaman weaknessesthreats). Mencocokkan faktor eksternal dan internal kunci adalah bagian yang paling sulit dalam mengembangkan Matriks SWOT dan membutuhkan penilaian yang baik dan tidak ada pencocokan yang terbaik (Arabzad et al., 2011).

Strategi So menggunakan kekuatan internal perusahaan untuk memanfaatkan peluang eksternal. Ini adalah posisi perusahaan yang sangat baik, dimana semua pimpinan organisasi akan mengarahkan organisasinya menuju ke kondisi yang memungkinkan mereka untuk menerapkan strategi SO, setelah sebelumnya menggunakan strategi WO, ST dan WT (Kabak et al., 2016).

Strategi Wo bertujuan untuk memperbaiki kelemahan internal dengan memanfaatkan peluang eksternal. Terkadang perusahaan memiliki peluang yang baik, namun karena kelemahan yang dimilikinya, dia tidak dapat memanfaatkan peluang tersebut menjadi sebuah keuntungan. (Kabak et al., 2016).

Strategi ST menggunakan kekuatan perusahaan untuk menghindari atau mengurangi pengaruh dari ancaman eksternal (Kabak et al., 2016).

Strategi WT adalah taktik defensif yang diarahkan pada pengurangan kelemahan 
internal dan menghindari ancaman eksternal. Sebuah organisasi menghadapi berbagai ancaman eksternal dan kelemahan internal akan berada pada posisi yang tidak aman. Kenyataannya, perusahaan seperti itu mungkin harus berusaha bertahan hidup, bergabung, mengurangi ukuran, mendeklarasikan kebangkrutan, atau memilih likuidasi (Kabak et al., 2016).

\section{Analisis Perubahan Lingkungan Eksternal (PESTEL)}

Analisa PESTEL adalah Analisis lingkungan makro sangat penting dalam menentukan faktor-faktor yang memiliki dampak langsung dan / atau dapat mempengaruhi arah strategis organisasi. Sejumlah konsep yang berbeda dapat digunakan untuk menganalisis lingkungan makro eksternal dalam upaya mengidentifikasi faktor-faktor yang mungkin berdampak pada organisasi, baik dalam hal menjadi ancaman atau peluang (Dale, 2005).

PESTEL (yang merupakan kependekan dari Politik, Ekonomi, Sosial-budaya dan Teknologi) analisis adalah pemindaian dari lingkungan makro eksternal di mana suatu perusahaan ada. Ini adalah alat yang berguna untuk memahami lingkungan politik, ekonomi, sosial-budaya dan teknologi tempat perusahaan beroperasi (Enz, 2010). Ini dapat digunakan untuk mengevaluasi pertumbuhan

atau penurunan pasar, dan dengan demikian posisi, potensi, dan arah bisnis. Penjelasan untuk tiap-tiap komponen adalah sebagai berikut, (David, 2009) :

1. Faktor-faktor politik termasuk peraturan pemerintah seperti undang-undang ketenagakerjaan, peraturan lingkungan, kebijakan perpajakan dan stabilitas politik.

2. Faktor ekonomi termasuk pertumbuhan ekonomi, suku bunga, inflasi dan nilai tukar mata uang. Ini mempengaruhi biaya modal dan biaya operasi suatu perusahaan.

3. Faktor sosial meliputi pertumbuhan populasi, demografi usia, gaya hidup dan mode, dan sikap terhadap kesehatan (mis. Gizi). Ini berdampak pada kebutuhan konsumen dan ukuran pasar potensial untuk barang dan jasa perusahaan.

4. Faktor teknologi adalah faktor-faktor yang memengaruhi hambatan untuk masuk, membuat atau membeli keputusan dan investasi dalam inovasi, seperti otomatisasi, insentif investasi, dan laju perubahan teknologi.

5. Environmental (Lingkungan)

Mencakup semua pengaruh yang dipicu oleh lingkungan sekitar, seperti (1) iklim, (2) cuaca, (3) kondisi geografis, pergantian iklim global, (5) kerusakan lingkungan dan lainnya 


\section{Legal}

Faktor ini memiliki sisi internal dan sisi eksternal. Ada aturan tertentu yang mempengaruhi lingkungan bisnis pada negara tertentu sementara ada juga aturan-aturan yang dibuat dan dipertahankan oleh bisnis itu sendiri. Analisis legal termasuk aturan konsumen, standar keselematan, aturan pekerja, dan lainnya.

\section{Internal dan Eksternal (IE) Matriks}

Langkah ringkasan dalam melakukan audit manajemen strategis internal adalah membangun Matriks Evaluasi Faktor Internal (IFE). Alat perumusan strategi ini merangkum dan mengevaluasi kekuatan dan kelemahan utama di area fungsional bisnis, dan juga memberikan dasar untuk mengidentifikasi dan mengevaluasi hubungan di antara area tersebut. Penilaian intuitif diperlukan dalam mengembangkan Matriks IFE, jadi penampilan pendekatan ilmiah tidak boleh diartikan sebagai teknik yang sangat kuat. A menyeluruh pemahaman tentang faktor-faktor yang dimasukkan lebih penting daripada angkaangka sebenarnya (David, 2009). Sebaliknya, matriks EFE akan berpegang pada konddisi eksternal perusahaan dengan mengacu pada kerangka PESTEL (David, 2009).
Daftar faktor strategis merupakan kumpulan dari situasi yang ada di dalam perusahaan saat ini dan bersifat urgent untuk dilakukan evaluasi menurut informan kunci penelitian. Disarankan membuat daftar kekuatan terlebih dahulu dan kemudian kelemahan. Penetapan bobot berkisar dari 0,0 (tidak penting) hingga 1,0 (semua penting) untuk setiap faktor. Bobot yang diberikan ke faktor tertentu menunjukkan kepentingan relatif dari faktor tersebut untuk sukses dalam industri perusahaan. Terlepas dari apakah faktor kunci adalah kekuatan atau kelemahan internal, faktor yang dianggap memiliki pengaruh terbesar pada kinerja organisasi harus diberi bobot tertinggi. Jumlah semua bobot harus sama dengan 1.0. Tetapkan peringkat 1 hingga 4 untuk setiap faktor untuk menunjukkan apakah faktor tersebut mewakili kelemahan utama (peringkat $=1$ ), kelemahan kecil (peringkat $=2$ ), kekuatan kecil (peringkat $=3$ ), atau kekuatan utama (peringkat $=4$ ). Perhatikan bahwa kekuatan harus menerima peringkat 3 atau 4 dan kelemahan harus menerima peringkat 1 atau 2. Dengan demikian, peringkat didasarkan pada perusahaan, sedangkan bobot pada langkah 2 berbasis industri. Kalikan bobot setiap faktor dengan peringkatnya untuk menentukan skor tertimbang untuk setiap variabel. Jumlahkan skor tertimbang untuk setiap 
variabel untuk menentukan skor total tertimbang untuk organisasi (David, 2009).

Terlepas dari berapa banyak faktor yang termasuk dalam Matriks IFE dan EFE, skor tertimbang total dapat berkisar dari yang rendah 1,0 hingga yang tertinggi 4,0, dengan skor rata-rata 2,5. Total skor tertimbang jauh di bawah 2,5 mencirikan organisasi yang lemah secara internal, sedangkan skor secara signifikan di atas 2,5 menunjukkan posisi internal yang kuat (David, 2009).

\section{METODOLOGI PENELITIAN}

\section{Pendekatan Penelitian}

Penelitian ini menggunakan pendekatan kualitatif dalam menjawab rumusan masalah penelitian. Penelitian kualitatif dapat memberikan wawasan tentang caracara baru bekerja dan bagaimana praktik kerja berkembang dalam interaksi seharihari serta bagaimana mereka terkait dengan pengaruh kontekstual di berbagai tingkatan (Garcia and Gluesing, 2013). Sehingga dengan demikian pendekatan kualitatif memberikan metode terbaik, paling ketat dan paling bernuansa yang tersedia bagi para peneliti untuk mengembangkan pemahaman tentang dampak konteks dan budaya nasional dan organisasi tentang potensi efektivitas program dan proses perubahan (Garcia and Gluesing, 2013). Dengan menggunakan metode kualitatif,
Duerr (2004) mampu mengungkap elemen struktural baru dalam organisasi yang mengalami perubahan yang sebelumnya tidak dieksplorasi - komponen kontemplatif dari suatu organisasi.

Hanya dengan mengamati dan mewawancarai peserta, peneliti dapat menemukan elemen-elemen struktural ini dan tidak akan tahu untuk mengajukan pertanyaan yang sesuai dalam studi kuantitatif dan berbasis survei tradisional. Karakteristik organisasi lain yang muncul atau berperan selama proses perubahan dan hampir tidak mungkin terungkap dengan menggunakan metode kuantitatif telah lebih dipahami dengan narasi dan studi kualitatif lainnya. Penting di antara karakteristik organisasi diam-diam ini adalah identitas organisasi dan bagaimana persepsi dan pemahaman tentang hal itu dapat menyebabkan resistensi terhadap perubahan dan beragam interpretasi proses perubahan di banyak tingkatan (Landau and Drori, 2008).

\section{Alur Pikir Penelitian}

Alur pikir menggabungkan informasi internal dan eksternal, informasi internal menggunakan framework ACCRE (Barney, 1991) yang menyatakan bahwa kerangka kerja untuk pemetaan internal melihat terhadap 5 aspek utama yakni Asset (A), Competence (C), Capabilities (C), Reource (R), dan Evaluation (E). Sementara kerangka 
kerja eksternal menggunakan framework PESTEL (Johnson et al., 2005) dimana kerangka kerja ini menggunakan 6 aspek pendekatan yakni Political (P), Economical (E), Social (S), Technology (T), Environmental (E), dan Legal (L).

Pada penelitian ini nantinya elemen dalam PESTEL dan ACCRE tidak digunakan seluruh komponennya, hal ini menyesuaikan dengan kondisi internal dan eksternal dari perusahaan freight forwarder. Gambar 1 menunjukkan alur pikir penelitian dengan meniadakan elemen legal (L) pada kerangka PESTEL dan menghilangkan elemen asset (A) dan evaluation (E). Alasan tidak meniadakan dua elemen pada elemen ACCRE karena pada penelitian ini fokusnya adalah SDM, sehingga penggunaan asset dan evaluation dapat dikesampingkan. Sementara komponen competence, capabilities, dan resource adalah sangat lekat kaitannya dengan SDM, sehingga guna mendapatkan pemetaan internal SDM yang holistik, maka penggunaan ketiga komponen diatas adalah yang paling representatif.

\section{Fokus dan objek Penelitian}

Fokus penelitian ini adalah pada perusahaan jasa, lebih spesifik lagi adalah pelayanan jasa pada bidang pelayanan peti kemas (freight forwarder). Penelitian ini dilakukan di salah satu perusahaan yang bergerak dibidang freight forwarder berlokasi di Surabaya. Demi kerahasisaan perusahaan, maka penulis tidak menuliskan nama perusahaan yang dimaksud, oleh karenanya hasil penelitian ini hanya bisa dipergunakan oleh perusahaan yang bersangkutan. Namun demikian, pendekatan dan analisis yang dipergunakan dalam penelitian ini dapat digunakan di perusahaan lain yang serupa untuk menentukan arah strateginya.

\section{Informan Penelitian}

Informan penelitian adalah person yang dianggap memiliki pengetahuan dan kapabilitas sehingga dengan pengetahuan dan kapabilitas yang dimiliki dapat dimanfaatkan oleh penulis untuk merumuskan langkah perbaikan dalam penelitian yang sedang dilangsungkan. Informan penelitian adalah person yang secara organik merupakan bagian dari perusahaan khususnya adalah mereka yang memegang jabatan struktural. Level manajer dan direktur adalah informan kunci yang dipergunakan dalam penelitian ini. Informan yang bersumber dari 2 orang direktur, yakni direktur independen dan direktur bagian pengembangan perusahaan diminta informasinya untuk membantu memetakan kondisi perusahaan yang saat ini dan terlebih lagi untuk kedepannya. Selanjutnya adalah mengambil 4 informan dari jajaran manajer, yakni manajer sales 
serta manajer accounting dan finance dari kantor pusat Jakarta dan perwakilan kantor Surabaya. Kedua manajer ini difungsikan untuk diambil informasinya dalam ranah menjalankan roda bisnis perusahaan, perlu diketahui bahwa perusahaan sangat menggantungkan roda bisnis perusahaannya dari peran 2 manajer ini. Pengembangan dan penghasilan akan sangat bergantung pada bagaimana kedua departemen ini memutar roda bisnisnya untuk menopang berat laju perusahaan.
Manajer sales akan memberikan informasi apakah kompetensi SDM sanggup dan mumpuni untuk mencari, memberikan service, serta menyelesaikan bisnis freight forwarding perusahaan dengan klien. Sementara manajer accounting dan finance akan memberikan informasi bagaimana SDM mengatur roda keuangan perusahaan sehingga kegiatan project besar perusahaan dapat terlaksana dengan baik tanpa hambatan dan kendala. Secara lebih detail, berikut profil informan penelitian.

Tabel 1

Informan Penelitian

\begin{tabular}{|c|c|c|}
\hline $\begin{array}{l}\text { Nama Informan } \\
\text { (Inisial Nama) }\end{array}$ & Jabatan & Keterangan \\
\hline HS & Direktur & Pemegang kendali perusahaan \\
\hline $\mathrm{TE}$ & Direktur & $\begin{array}{l}\text { Penanggung Jawab Pengembangan } \\
\text { Freight Forwarding }\end{array}$ \\
\hline $\mathrm{SN}$ & Manajer & $\begin{array}{l}\text { Penanggung jawab kegiatan accounting } \\
\text { dan finance }\end{array}$ \\
\hline PS & Manajer & Penanggung jawab kegiatan sales \\
\hline DR & Manajer & Penanggung jawab kegiatan sales \\
\hline $\mathrm{AH}$ & Manajer & $\begin{array}{l}\text { Penanggung jawab kegiatan accounting } \\
\text { dan finance }\end{array}$ \\
\hline AS & Manajer & Penanggung jawab kegiatan operasional \\
\hline $\mathrm{HE}$ & $\begin{array}{l}\text { Pelanggan (pengguna } \\
\text { jasa) }\end{array}$ & Pelanggan loyal di tahun 2019 \\
\hline
\end{tabular}

Sumber : Data penelitian, 2019

\section{Metode Pengumpulan dan Analisa Data}

Metode pengumpulan data terdiri dari dua bagian. Pertama adalah tinjauan komprehensif atas literatur masa lalu dan bagian kedua melibatkan serangkaian wawancara dengan eksekutif manajemen di perusahaan freight forwarder. Literatur yang diperoleh untuk pengumpulan data awal berasal dari berbagai database seperti Emerald yang nantinya akan digunakan sebagai acuan referensi untuk membantu mempertajam analisis (Ab-Talib, 2014).

Teknik analisis data menunjukkan perlakuan terhadap data yang telah terkumpul dari kegiatan pengumpulan data primer dan data sekunder. Dikarenakan 
penelitian ini mengusung tema kualitatif, maka teknik analisis data juga menggunakan model kualitatif. (Zhu, 2004) dalam model penelitian kualitatifnya menyebutkan bahwa semua data yang digunakan dalam analisis didasarkan pada informasi yang diperoleh dalam studi kasus dan, khususnya, wawancara. Informasi yang berkaitan dengan profil perusahaan mencakup sejumlah data statistik yang disediakan oleh catatan perusahaan. Analisa data menggunakan pendekatan IFE dan EFE Matriks (David, 2009), untuk memetakan skor dan pembobotan dari masing-masing kekuatan internal dan perubahan eksternal yang kemudian akan digabungkan dengan TOWS matriks untuk menyimpulkan strategi apa yang memungkinkan untuk dilakukan oleh manajemen perusahaan (Koo et al., 2011).

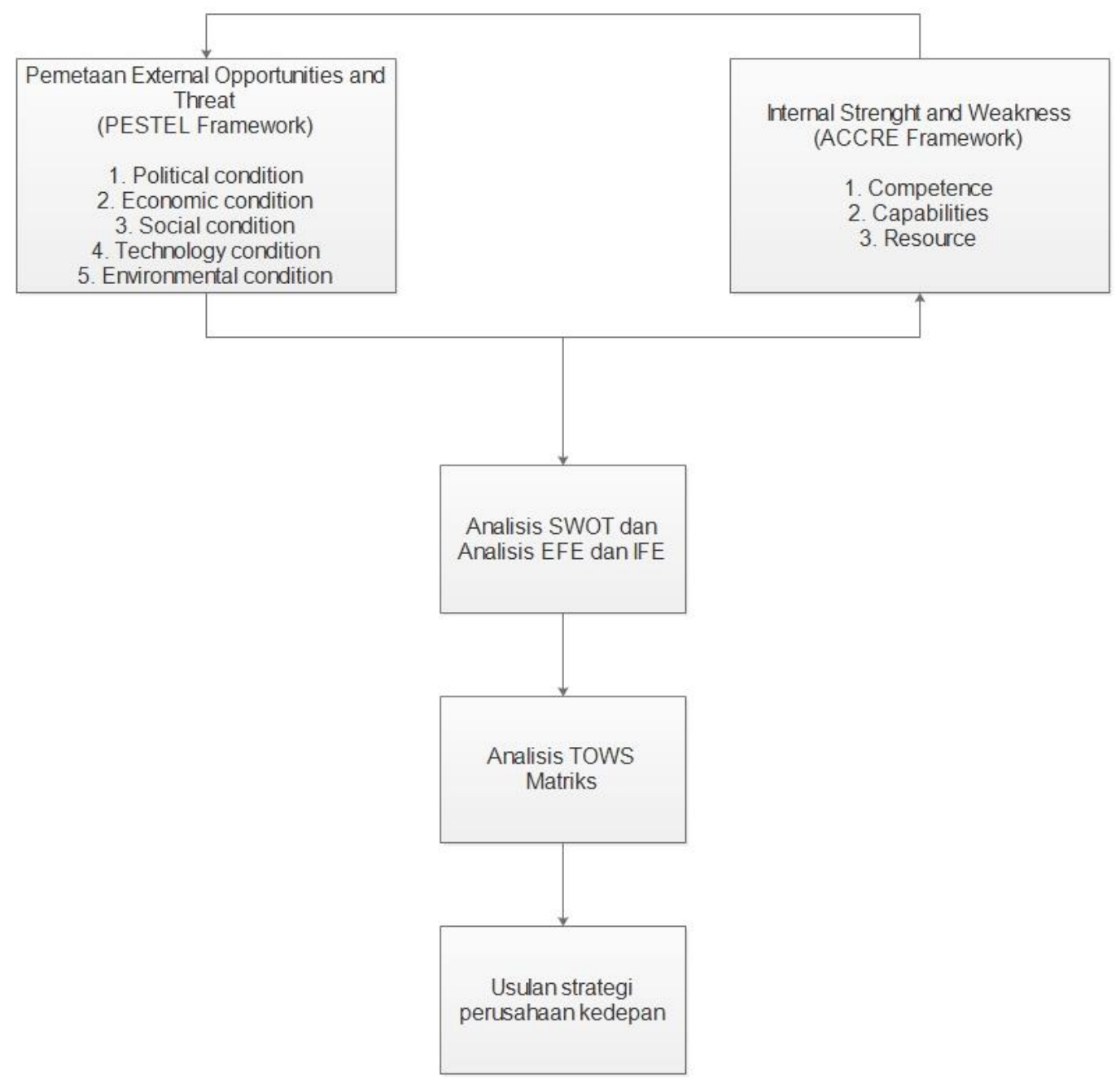

Gambar 1

Alur Pikir Penelitian 


\section{HASIL DAN PEMBAHASAN}

\section{Analisis Kekuatan Internal (IFE Matriks)}

Berdasarkan hasil wawancara dengan informan penelitian guna memberikan penilaian terhadap internal strategik perusahaan terhadap komponen internal matrix (strength and weakness) terjabar sebagai berikut. Berdasarkan hasil data pada tabel 2 terdapat angka dalam kurung pada tiap indikator Strenght dan Weakness angka tersebut merupakan angka dummy pembobotan untuk menentukan tingkat bobot dimulai dari yang paling rendah hingga yang paling tinggi. Dalam matriks IFE pembobotan diperbolehkan untuk bernilai sama, artinya tidak ada bobot yang lebih tinggi atau rendah pada indikator Strength dan Weakness. Perhitungan angka dummy adalah murni konsensus informan penelitian yang hasilnya dianggap sah dan mewakili perusahaan, dikarenakan para informan merupakan personil kunci yang memiliki otoritas dan kewenangan terhadap perusahaan. Rumus perhitungan angka pembobotan adalah sebagai berikut:

$$
\text { Bobot }=\frac{\text { Angka dummy }}{\text { Total dummy }}
$$

Menggunakan perhitungan diatas, maka bobot pada tiap indikator trenght dan Weakness akan diketahui. Sebagai catatan nilai bobot total haruslah 1,00 tidak boleh lebih dan kurang. Berdasarkan hasil wawancara dengan informan maka nilai untuk tiap parameter terjabar seperti pada tabel 2, selanjutnya adalah penentusan Skor. Skor adalah hasil perkalian antara nilai bobot dan nilai rating dan dijumlahkan antara Strenght dan Weakness. Sehingga dapat disimpulkan bahwa nilai internal matrix tahun 2019 berdasarkan konsensus dari informan penelitian adalah 2,46.

\section{Analisa Perubahan Eksternal (EFE Matriks)}

Berdasarkan hasil penilaian terhadap internal strategik perusahaan terhadap komponen external matrix (opportunities and threat) terjabar sebagai berikut.

Berdasarkan hasil data pada tabel 3 terdapat angka dalam kurung pada tiap indikator opportunities dan threat angka tersebut merupakan angka dummy pembobotan untuk menentukan tingkat bobot dimulai dari yang paling rendah hingga paling tinggi. Dalam matriks EFE pembobotan diperbolehkan untuk bernilai sama, artinya tidak ada bobot yang lebih tinggi atau rendah pada indikator opportunities dan threat. Perhitungan angka dummy adalah murni konsensus informan penelitian, hasilnya dianggap sah dan mewakili perusahaan, dikarenakan para informan merupakan personil kunci yang memiliki otoritas dan kewenangan terhadap perusahaan. Rumus perhitungan angka pembobotan adalah sebagai berikut : 


$$
\text { Bobot }=\frac{\text { Angka dummy }}{\text { Total dummy }}
$$

Menggunakan perhitungan diatas, maka bobot tiap indikator opportunities dan threat akan diketahui. Sebagai catatan nilai bobot total haruslah 1,00 tidak boleh lebih dan kurang. Berdasarkan hasil wawancara dengan informan maka nilai untuk tiap parameter terjabar seperti pada tabel 3, selanjutnya adalah penentusan Skor. Sehingga didapatkan kesimpulan bahwa nilai external matrix tahun 2019 berdasarkan konsensus dari informan penelitian adalah 2,30 .

Tabel 2

Internal Matrix of SOWT (Strength and Weakness)

\begin{tabular}{lccc}
\multicolumn{1}{c}{ Faktor Strategis } & Bobot & Rating & Skor \\
Strength Factor / Faktor Kekuatan & & & \\
\hline Member Worldwide project / world cargo alliance (3) & 0,11 & 4 & 0,44 \\
Perusahaan go public (4) & 0,13 & 3 & 0,39 \\
Memiliki jaringan internasional (3) & 0,11 & 3 & 0,33 \\
Total solution logistics (2) & 0,07 & 3 & 0,21 \\
Pengalaman lebih 20 tahun (3) & 0,11 & 3 & 0,33 \\
Weakness Factor / Fakor Kelemahan & & & \\
Karyawan operasional tidak bisa berbahasa inggris (2) & 0,07 & 1 & 0,07 \\
Kurangnya kompetensi karyawan (3) & 0,11 & 2 & 0,22 \\
Belum mempunyai peralatan sendiri (2) & 0,07 & 2 & 0,14 \\
Kurangnya tenaga ahli dan planner projek (3) & 0,11 & 1 & 0,11 \\
Banyaknya rangkap jabatan (3) $\quad 0,11$ & 2 & 0,22 \\
\hline \multicolumn{1}{c}{ TOTAL } & $\mathbf{1 , 0 0}$ & $\mathbf{2 , 4 6}$
\end{tabular}

Sumber : Hasil olah data penelitian, 2019

Tabel 3

External Matrix of SOWT (opportunities and threat)

\begin{tabular}{|c|c|c|c|}
\hline Faktor Strategis & Bobot & Rating & Skor \\
\hline \multicolumn{4}{|l|}{ Opportunities Factor / Faktor Peluang } \\
\hline Bisnis logistik yang berkembang (3) & 0,10 & 4 & 0,40 \\
\hline Proyek infrastuktur yang meningkat (4) & 0,12 & 4 & 0,48 \\
\hline Perdagangan internasional yang meningkat (3) & 0,10 & 3 & 0,30 \\
\hline Perkembangan e-commers (3) & 0,10 & 3 & 0,30 \\
\hline Perkembangan teknologi dan SI $(3,5)$ & 0,12 & 3 & 0,36 \\
\hline \multicolumn{4}{|l|}{ Threat Opportunities / Faktor Ancaman } \\
\hline Masuknya perusahaan logistics asing (4) & 0,12 & 2 & 0,24 \\
\hline Kompetitor lokal yang banyak berbenah $(3,5)$ & 0,12 & 2 & 0,24 \\
\hline $\begin{array}{l}\text { Banyaknya customer yang mempunyai usaha di bidang logistic } \\
\text { (3) }\end{array}$ & 0,10 & 1 & 0,10 \\
\hline Masuknya tennaga logistic asing $(3,5)$ & 0,12 & 2 & 0,24 \\
\hline $\begin{array}{ll}\text { TOTAL } \\
\end{array}$ & 1,00 & & 2,30 \\
\hline
\end{tabular}

Sumber : Hasil olah data penelitian, 2019 


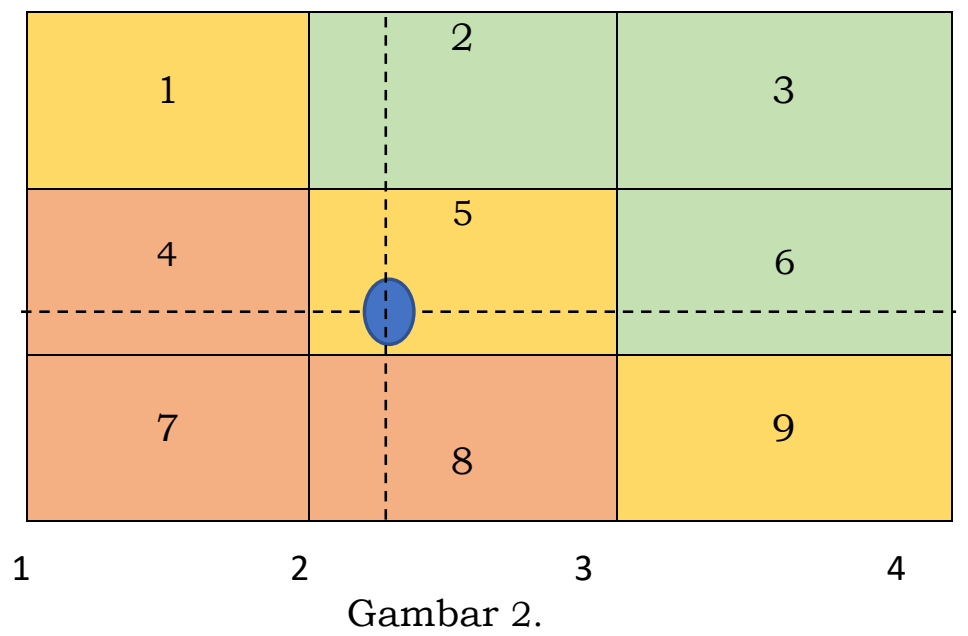

Internal Eksternal Matriks Plotting Diagram

Menggabungkan data yang tersaji pada tabel 3 dan tabel 4, maka didapatkan plot positioning perusahaan pada tingkat medium atau hold and maintain, yang artinya adalah fokus perusahaan untuk saat ini adalah ke market penetration dan pengembangan produk/ layanan. Strategic positioning terhadap kondisi internal dan eksternal perusahaan berada pada level yang mengharuskan perusahaan berfokus pada memberikan value kepada pelanggan dengan salah satu caranya adalah mengembangkan produk baru.

Mengembangkan produk baru tidak harus membuat produk yang benar-benar baru, namun dapat pula menggunakan produk lama yang dipoles sehingga memiliki tampilan baru yang akan menaikkan value dari layanan tersebut yang secara langsung akan dirasakan oleh pelanggan manfaatnya. Sementara market penetration adalah berfokus untuk menembus pasar yang benar-benar baru atau menggeluti lebih intens pasar yang ada saat ini. Hal ini akan berdampak pada cost perusahaan namun dampak yang akan ditimbulkan adalah besar dikemudian hari, ibarat menanam bibit hari ini dan nanti akan menuai hasilnya dikemudian hari.

\section{Usulan Strategi Perusahaan}

Usulan strategi perusahaan diturunkan dari SWOT yang telah dilakukan oleh perusahaan sebelumya, sehingga usulan ini nantinya akan dapat diterima oleh pihak manajemen perusahaan guna membantu dalam memenangkan persaingan dengan menggunakan basis terknologi.

1. Strategi SO

a. Meningkatkan kerjasama dengan perusahaan lainnya diluar negeri (dengan catatan perusahaan yang memiliki line bisnis sama)

b. Memanfaatkankekuatan jaringan

c. Peningkatan kemampuan elektronik bagi bisnis 
2. Strategi WO
a. Pendidikan dan pelatihan penguasaan bahasa inggris
b. Mengevaluasi standar kompetensi baru
c. Merekrut tenaga-tenaga pengalaman dari luar terutama bidang sales

3. Strategi ST
a. Strategi kolaborasi dengan beberapa perusahaan
b. Peningkatan kerjasama dengan vendors.
c. Peningkatan layanan bagi pelanggan

4. Strategi WT
a. Meningkatkan alignment karyawan
b. Meningkatkan
enggagement karyawan dengan meningkatkan program pengembangan karyawan dan penghargaan terhadap karyawan.

Karena strategi adalah alat untuk mencapai tujuan penting, tidak ada artinya mengembangkan strategi tanpa tujuan strategis masing-masing. Pertimbangan yang menarik dan berguna tentang perumusan strategis akan mengangkat masalah urutan sarana (yaitu strategi) dan tujuan (yaitu tujuan strategis). Untuk strategi di tingkat atas tidak boleh ada tujuan yang telah ditentukan sebelumnya yang mungkin membatasi transformasi organisasi yang diperlukan dalam menanggapi perubahan lingkungan eksternal.

Dalam melakukan analisis SWOT di tingkat yang lebih rendah, pertimbangan harus diberikan untuk menyelaraskan tujuan tingkat atas, yaitu dalam mendukung pencapaian tujuan tingkat atas apa kekuatan dan kelemahan internal yang dimiliki unit terkait dan peluang serta ancaman eksternal yang akan mereka hadapi dengan menggunakan pendekatan hierarkis ini, pemanfaatan sumber daya dan upaya karyawan dapat diselaraskan untuk menuai manfaat sinergis (Koo, 2007).

\section{KESIMPULAN}

Penentuan strategi kedepan bagi perusahaan guna memenangkan persaingan di kancah nasional memerlukan usaha dan perubahanperubahan utamanya di lingkungan internal. Hasil konsensus yang diberikan oleh informan penelitian memainkan peran penting dalam menentukan arah strategi perusahaan kedepannya. Hasil IFE dan EFE matriks mencerminkan itu semua, beserta nilai yang tertuang didalamnya merupakan hasil keputusan yang bersifat visioner kedepan dari para informan penelitian. Informan penelitian berusaha untuk mengarahkan perusahaan ini menuju lebih baik dengan berusaha menghadirkan faktor penentu 
apa saja yang menjadi kekuatan internal dan faktor apa saja yang telah mengalami perubahan di lingkungan eksternal.

TOWS matriks yang menggandengkan antara kekuatan internal dan perubahan eksternal memberikan pandangan dan arahan kepada pemangku kebijakan di perusahaan agar mengambil jalan dan langkah tersebut. pada tiap-tiap startegi baik SO, WO, ST, dan WT telah didesain dan dirancang untuk dapat dan mampu mengkompensasi faktor internal dan eksteral, sehingga usulan strategi ini menjadi usulan yang bersifat jangka pendek yang dapat diterapkan oleh manajemen perusahaan segera.

Kedepannya usulan strategi ini akan tetap valid selama pemetaan SWOT untuk lingkungan internal dan eksternal tidak akan mengalami perubahan drastis, yang maka dengan demikian apabila telah terjadi perubahan drastis di kedua lingkungan tersebut maka secara otomatis usulan strategi dalam TOWS matriks akan diubah mengikuti perubahan di kedua lingkungan tersebut.

\section{IMPLIKASI PENELITIAN}

Penelitian ini dapat dijadikan sebagai rujukan bagi perusahaan lain di bidang freight forwarder untuk menentukan arah strategi perusahaan kedepannya, namun demikian hasil ini hanya valid pada perusahaan yang menjadi objek penelitian, seluruh variabel harus diubah dan disesuaikan dengan kondisi perusahaan masing-masing agar hasil strategi yang diusulkan menjadi valid. Dalam bidang strategic penelitian ini akan memberikan gambaran bahwa menggunakan model SWOT, TOWS, IFE dan EFE matriks masih dapat dipergunakan untuk membantu menentukan arah strategi perusahaan di era dan zaman sekarang, meskipun model pengembangan strategi tersebut telah berusia lebih dari 20 tahun sejak pertama kali digunakan.

\section{DAFTAR PUSTAKA}

Ab-Talib, M.S, and Abdul Hamid, A.B. (2014),"Halal logistics in Malaysia: a SWOT analysis", Journal of Islamic Marketing, Vol. 5 No. 3 pp. $322-343$

Aktan, C.C. (2008), "Stratejik yönetim ve stratejik planlama”, Çimento Is _veren Dergisi, Vol. 22, pp. 4-4.

Arabzad, S.M., Ghorbani, M., Razmi, J. and Shirouyehzad, H. (2011), "Employing fuzzy TOPSIS and SWOT for supplier selection and order allocation problem", The International Journal of Advanced Manufacturing Technology, Vol. 76 No. 5-8, pp. 803-818

David, F.R. (2009), Strategic Management Concept and Cases, 13th ed., Pearson, NJ. 
Dale, C. (2005). Strategic management for tourism: Resource guide. London: The Higher Education Academy, Hospitality, Leisure, Sport and Tourism Network.

Ding, J.F. and Tsai, P.P. (2012), "Evaluating quality improvement of service recovery for ocean freight forwarders in Taiwan", Information technology journal, Vol. 11 No.11, pp.15791587.

Duerr, M. (2004). The contemplative organization. Journal of Organizational Change Management, 17(1), 43-61. https://doi.org/10.1108/09534810410511297

Enz, C. A. (2010). Hospitality strategic management: Concepts and cases (2nd ed.). New York, NY: John Wiley \& Sons.

Garcia, D., and Gluesing, J. C. (2013). Qualitative research methods in international organizational change research. Journal of Organizational Change Management, 26(2), 423444. https://doi.org/10.1108/09534811311328416

Global Freight Forwarding report (2016), available at: www.ti-insight.com

Kabak, M., Dagdeviren, M. and Burmao glu, S. (2016), "A hybrid SWOT-FANP model for energy policy making in Turkey”, Energy Sources, Part B: Economics, Planning, and Policy, Vol. 11 No. 6, pp. 487-495

Kilibarda, M., Nikolicic, S., and Andrejic M. (2016),"Measurement of logistics service quality in freight forwarding companies: a case study of the Serbian market", International Journal of Logistics Management, Vol. 27. No. 3

Koo, L.C., Koo, H. and Liu, S.B. (2009), "Strategies for Macau's development", Proceedings of Rising Macao: Review and Prospects on the 10th Anniversary of Macao SAR, International Conference, Macao Polytechnic Institute, 21-22 April

Koo, H., Chau, K.Y., Koo, L.C., Liu, S.B., and Tsui S.C. (2011), "A structured SWOT approach to develop strategies for the government of Macau, SAR", Journal of Strategy and Management, Vol. 4 No. 1, pp. 62-81

Landau, D. and Drori, I. (2008). Narratives as sensemaking accounts: the case of an R\&D laboratory. Journal of Organizational Change Management, 21(6), 701-720. https://doi.org/10.1108/09534810810915736

Learned, E.P., Christensen, C.R., Andrews, K.R. and Guth, W.D. (1969), Business Policy: Text and Cases, RD Irwin, Homewood, IL

Lynch, R. (2012), Strategic Management, 6th ed., Pearson, Rorolito, Lombarda

Panagiotou, G. (2003), "Bringing SWOT into focus", Business Strategy Review, Vol. 14 No. 2, pp. 8-10.

Proctor, R.A. (1992), "Structured and creative approaches to strategy formulation", Management Research News, Vol. 15 No. 1, pp. 13-19. 
Weihrich, H. (1982), "The TOWS matrix: a tool for situational analysis", Journal of Long Range Planning, Vol. 15 No. 2, pp. 54-66.

Zhu, Y. (2004). Responding to the challenges of globalization: Human resource development in Japan. Journal of World Business, 39(4), 337-348. 